RESEARCH / INVESTIGACIÓN

\title{
Formulation and organoleptic evaluation of Poly Herbal Cream of Punica, Neem, Carrot \& Jamun as Active Ingredients
}

Puja Saha ${ }^{1 *}$, Jayashree Bhowmick², Anupam Saha ${ }^{3}$

DOI. 10.21931/RB/2021.06.03.5

Abstract: Assuming that herbal preparation is better with fewer side effects than synthetics, natural treatments are more effective than allopathy in terms of side effects for better human body healing. Herbal products have a growing demand in the world market, and the plants have been reported in the literature as having various pharmacological activities such as anti-microbial, anti-oxidant, anti-inflammatory activity, [UdM04] anti-cancer, anti-diabetic. The purpose of this study was to develop anti-aging poly-herbal cream by mixing the extract of Punica leaf, Neem Oil, Jamun powder, Carrot powder as the main ingredient, and then creams were developed based on the anti-oxidant ability of herbal extracts and performed their evaluation study. Punica granatam leaves were shade dried and extracted using the Soxhlet method with different solvents such as n-hexane, benzene, and alcohol.[UdM05] Fine extract powder was collected and removed distilled water thoroughly. The cream was formulated into different concentrations, namely F1, F2, F3, and F4. Similar types of research with similar components have been reported, but in this experiment, the formulation is different, and this work is kept cost-efficient and straightforward; it's an attempt to reduce few components and prepare cream and evaluate its potential. According to The International Council for Harmonization of Technical Requirements for Pharmaceuticals for Human Use ICH[UdMO6] guidelines, the cream was stable during stability studies, and F3 turned out to be a better formulation than the other three.

Key words: Anti-aging, Poly-herbs, Herbal Remedy, Herbal Cream, Pharmaceutical Cream, Skin Care.

\section{Introduction}

Dermal layer aging results from continual deterioration due to cellular DNA and protein; aging is classed into 2 distinct varieties: sequential skin aging and photo-aging. Each type has distinct clinical and historical options, and sequential skin aging is a universal and specific process characterized by physiological alteration in skin function. Within the aging process, keratinocytes cannot create a helpful stratum corneum, and the rate of formation from neutral lipids slows down, leading to dry pale skin with a wrinkle. In contrast, photo-aging is caused by the disorganization of stratum and dermal parts associated with physiological state and helio dermatitis. Herbs and plants have already proved helpful as a tool in the practice of medicine ${ }^{1-3}$.

Cosmetic merchandise is used to shield pores and skin in opposition to exogenous and endogenous dangerous retailers and beautify the splendor and elegance of skin and the usage of cosmetics now not only handiest growing an appealing outside look, but also towards accomplishing sturdiness of suitable fitness via way of means of decreasing skin disorders ${ }^{3-8}$. The artificial or herbal substances found in skincare formulation that helps the health, texture, and integrity of dermis, moisturizing and preserving the pliancy of the skin with the aid of using decreasing the type I collagen, photo-protection, and plenty more, and this belongings of beauty is because of the presence of substances in cosmetics as it allows to lessen the production of loose radicals in the skin and manage the dermal residences which is the obstruction to penetrate the skin for an extended time ${ }^{3,5,6}$. Cosmetic merchandise is the satisfactory desire to lessen dermal problems like hyperpigmentation, skin wrinkling, skin aging, problematic pores, rough skin texture, etc. The need for natural cosmetics is swiftly increasing, and the growth is because of the supply of recent ingredients, the monetary rewards for growing hitting merchandise, customer needs, and higher expertise in dermal biology $y^{3,5,9-11}$. The plant parts utili- zed in cosmetic products should have medicinal properties like anti-inflammatory, anti-oxidant, emollient, anti-seborrheic, antiseptic, anti-bacterial activities, etc. Herbal merchandise declares to have fewer adverse effects, normally visible with merchandise containing artificial agents. The marketplace studies suggest a rise in the trade with the cosmetic industries, a prime function in fueling this international call for herbals ${ }^{12-14}$.

\section{Punica leaf, part of the tree pomegranate}

$P$. granatum is one of the most common and potential plants for medicine in managing various ailments ${ }^{15}$. Punica granatum L. (belongs to the family Punicaceae) has been used to treat many ailments. Various plant parts have been scientifically tested for various pharmacological activities, such as potent antioxidative ${ }^{15,16}$, anti-inflammatory, anti-bacterial, anti-microbial, anti-fungal properties, anti-hypertensive, and antiproliferative properties ${ }^{17,18}$. Pomegranate has excellent potential to be developed for use in dermal products ${ }^{19}$. Chlorophyll-a extracted from pomegranate leaf and stem may be a potential source and can supply natural or herbal colorants for the coating enterprises and nail varnish. Pomegranate leaf extracts act on inhibiting the development of obesity and hyperlipidemia in obese mice fed with a high-fat $\operatorname{diet}^{20-22}$.

\section{Almond oil is the oil isolated from Almonds}

The almond Prunus dulcis (Mill) D.A. Webb (subfamily Prunoideae of family Rosaceae) contains fixed oil, phenolic compounds abundant in almonds; it also contains and some micronutrients, vitamins, minerals and has different pharmacological activities ${ }^{23-26}$. Almond seeds and oil have cardio-protective, immune-stimulant effects, anti-inflammatory, and reduce irritable bowel syndrome symptoms, and they are also helpful in treating constipation ${ }^{27,28}$. Almond oil has also been used to

\footnotetext{
Assistant Professor, Department of Pharmaceutics, School of Pharmacy, Seacom Skills University, Bolpur, Birbhum.

${ }^{2}$ Graduated B.Pharm, Bharat Technology, Uluberia, Howrah.

${ }^{3}$ Graduated M.Pharm, Pharmacology, NSHM College Of Pharmaceutical Technology, NSHM Knowledge Campus, B.L. Rd, Kolkata.
} 
treat dry skin disorders like psoriasis, eczema, and many more disorders in ancient treatment cultures but today it is used in aromatherapy and for producing many skin-hair cosmetics ${ }^{29}$.

\section{Jamun powder is made from sun-dried Jamun Seeds}

The black Jamun (Syzygium cumini L.) is an important indigenous plant of Myrtaceae, commonly known as jamun or Indian blackberry, originally from Indonesia and India, which has anti-oxidant solid antigenotoxic potential ${ }^{32,33}$. The fruit pulp is sweet, and the seeds are acidic and sour. The presence of oxalic, gallic, tannic acids and other alkaloids creates one to feel such an astringency taste. The pulp and seeds are used for traditional medicine against diabetes, diarrhea, and ringworm infection also protect against radiation-induced sickness $s^{32,34-37}$. It is very beneficial as it has anti-diabetic, cytoprotective, anticoagulant, analgesic and anti-inflammatory, anti-cancerous, anti-microbial, anti-oxidant, hypo-lipidemic, hepato-protective properties $35,38,39$.

\section{Carrots}

(Daucus carota) are essentially root veggies belonging to the family of Apeaceae or Umbelliferrous. These veggies are believed to have originated approximately 5000 years ago. Carrots are to be had in diverse, colorful variations like pink orange, white, purple, etc; however, the maximum usually observed variants are pink carrots and orange carrots. Carrots have anti-oxidants, which enables in regaining the misplaced glow of the skin. It helps in imparting remedies from scars and blemishes. Carrot is a unique anti-growing old compound due to the presence of Vitamin A.

Additionally, a considerable quantity of Vitamin C. Vitamin $A$ acts as an excellent anti-oxidant, fights with the free radicals of the body, stabilize them, and stops them from unfavorable our pores of skin cells and accordingly prevents the symptoms of growing old like wrinkles, pigmentation, and choppy pores and skin tone. Vitamin $\mathrm{C}$ enables the prevention of wrinkles using assisting the manufacturing of collagen in the body, which is a crucial protein required for retaining pores and skin elasticity. Carrot is likewise a wealthy supply of $\beta$-carotenoids, which boom or trigger skin immunity in opposition to solar rays and heals sunburns ${ }^{40-43}$.

\section{Neem tree}

(Azadirachta indica) is a local, evergreen, tropical tree to India ${ }^{44}$. Neem is a versatile, multifarious tree with a great capacity to own the most beneficial non-wooden products. Neem has various medicinal properties, including anti-cancer properties. In India, Neem is called the village of pharmacy due to its recovery versatility, and it's been utilized in Ayurvedic medication for extra than 4,000 years because of its medicinal properties $^{44-47}$. Azadirachtin is the principal compound of the neem oil with insecticidal activity ${ }^{48}$. Neem extracts were also reported to possess inhibitory effects on several cancer cell lines such as breast, gynecological, gastrointestinal, hematological, prostate, and skin cancers. Several active chemical compounds were discovered in neems, such as Nimbin, Nimbin, Saladin, azadirachtin (AZA), glycosides, and dihydrochalcone polyphenolics, coumarin, and tannins ${ }^{49-51}$. Pharmacological activities have been reported, including anti-bacterial, anti-inflammatory, anti-fungal, anti-arthritic, anti-pyretic, anti-gastric ulcer, hypoglycemic, and anti-tumor activities ${ }^{46,49,52-54}$.

\section{Grapeseed oil}

Is obtained from the seeds of grapes, and it was a by-product of winemaking and had many uses ranging from cooking cosmetics in controlling several diseases and wound healing potential ${ }^{55-57}$. Vitis vinifera $L$., which is commonly called grape used as a food and a beverage ${ }^{58}$. It is widely used as cooking oil, in skin care applications, and also as cosmetics. The grape seed oil contains 0.8 to $1.5 \%$ of phenols, steroids, and minor amounts of vitamin E. The grape seed oil was reported to possess the highest gallic acid, anti-oxidant, epicatechin, proanthocyanidins, catechin, and procyanidins. It has anti-oxidant, anti-fungal, anti-bacterial, antiviral, and anti-inflammatory activities ${ }^{59,60}$.

\section{Peppermint oil}

(Mentha piperita) extracted from peppermint leaves is an excellent gastric stimulant, carminative, which has also been used in cosmetic formulations as a perfume component and a general skin conditioning agent ${ }^{61,62}$. Peppermint (Mentha $\times$ Piperita) is a hybrid mint, which is a cross between Water mint (Mentha aquatica) and Spearmint (Mentha spicata) that is thought to be grown naturally62,63.

Similar types of research with similar Active Pharmaceutical Ingredients API have been reported. However, in this experiment, the formulation is different, and in each formulation, peppermint oil is used as the flavoring agent, whereas in the literature review, it is found that each formulation has a different flavoring agent. This work is kept cost-efficient and straightforward, it's an attempt to omit few components and prepare cream and evaluate its potential.

\section{Materials and methods}

The plan of work and the procedure followed for this experiment were performed by Matangi and the team in $2014^{3}$. The experiment was performed in Bharat Technology, Uluberia, in 2018 as an academic project for the partial fulfillment of a Bachelor of Pharmacy degree.

\section{Materials}

Glycerin, Propylene Glycol, Zinc oxide, Micro Crystalline Cellulose, Sodium alginate, Methylcellulose, Beeswax, Sodium benzoate/paraben, Almond oil, Punica leaves, Neem oil, Jamun powder, Carrot powder, Vitamin E, Grapeseed oil, Peppermint oil, and Purified water.

\section{Preparation of Punica leaf extract}

Punica granatum leaves were bought from the market and dried. The dried leaves were ground to a fine powder in a suitable grinder mixture. Shade dried powder was extracted using a Soxhlet extractor with hexane, alcohol, and distilled water separately to get the semisolid extract. The organic solvents were then recovered by steam distillation. The extracts were then concentrated to remove wetness under reduced pressure and controlled temperature, respectively, and they were preserved in a refrigerator.

\section{Preparation of Jamun Seeds powder}

Black Jamun (Syzygium cumini L.) were bought from the market, and the seeds are separated from the freshly part of the fruit, washed adequately, and dried. The seeds were dried under the sun for a week. Seeds were pounded along with the outer skin and made into a fine powder. 


\begin{tabular}{|c|c|c|c|c|c|}
\hline Ingredients & Category & $\underline{\text { F1 }}$ & $\underline{\mathbf{F} 2}$ & $\underline{\text { F3 }}$ & $\underline{\text { F4 }}$ \\
\hline Jamun Powder & API* & $5 \mathrm{~g}$ & $5 \mathrm{gm}$ & $5 \mathrm{gm}$ & $5 \mathrm{gm}$ \\
\hline $\begin{array}{c}\text { Punica leaf } \\
\text { extract }\end{array}$ & API & $2 \mathrm{ml}$ & $2 \mathrm{ml}$ & $2 \mathrm{ml}$ & $2 \mathrm{ml}$ \\
\hline Neem Oil & API & $2 \mathrm{ml}$ & $2 \mathrm{ml}$ & $2 \mathrm{ml}$ & $2 \mathrm{ml}$ \\
\hline Carrot Powder & $\begin{array}{c}\text { API + Vitamin A } \\
\text { Source }\end{array}$ & $3 \mathrm{gm}$ & $3 \mathrm{gm}$ & $3 \mathrm{gm}$ & $3 \mathrm{gm}$ \\
\hline Glycerin & Moisturizer & $3 \mathrm{ml}$ & $3 \mathrm{ml}$ & $3 \mathrm{ml}$ & $3 \mathrm{ml}$ \\
\hline Propylene Glycol & $\begin{array}{l}\text { Moisturizer + } \\
\text { Binder }\end{array}$ & $3 \mathrm{ml}$ & $3 \mathrm{ml}$ & $3 \mathrm{ml}$ & $3 \mathrm{ml}$ \\
\hline $\mathrm{ZnO}$ & Skin whitener & $3 \mathrm{gm}$ & $3 \mathrm{gm}$ & $3 \mathrm{gm}$ & $3 \mathrm{gm}$ \\
\hline Methyl Cellulose & Polymer & $5 \mathrm{gm}$ & - & - & - \\
\hline Sodium Alginate & Polymer & - & $2 \mathrm{gm}$ & $5 \mathrm{gm}$ & - \\
\hline $\begin{array}{c}\text { Microcrystalline } \\
\text { Cellulose }\end{array}$ & Polymer & - & $3 \mathrm{gm}$ & - & $5 \mathrm{gm}$ \\
\hline Cetyl Alcohol & $\begin{array}{c}\text { Surfactant }+ \\
\text { emollient }\end{array}$ & $1 \mathrm{ml}$ & $1 \mathrm{ml}$ & $1 \mathrm{ml}$ & $1 \mathrm{ml}$ \\
\hline Beeswax & Base & $3 \mathrm{gm}$ & - & $3 \mathrm{gm}$ & - \\
\hline Grapeseed Oil & Base & - & $2 \mathrm{ml}$ & - & - \\
\hline Almond Oil & Base & $2 \mathrm{ml}$ & $2 \mathrm{ml}$ & $2 \mathrm{ml}$ & $2 \mathrm{ml}$ \\
\hline Stearic acid & Base & - & - & - & $2 \mathrm{gm}$ \\
\hline Lanolin & Base & - & - & - & $1 \mathrm{gm}$ \\
\hline Sodium Benzoate & Preservative & $2 \mathrm{gm}$ & $2 \mathrm{gm}$ & $2 \mathrm{gm}$ & $2 \mathrm{gm}$ \\
\hline Peppermint Oil & Flavoring agent & $2 \mathrm{ml}$ & $2 \mathrm{ml}$ & $2 \mathrm{ml}$ & $3 \mathrm{ml}$ \\
\hline Purified water & Vehicle & QS* & QS & QS & QS \\
\hline
\end{tabular}

*API - Active Pharmaceutical Ingredient; QS - Quantity as required.

Table 1. Formulation Table.

\section{Cream Formulation}

The formula for the cream is given in Table No. 1.

\section{Method For Preparation Of Cream}

Shade-dried Punica leaf powder was put separately in a soxhlet extractor, and then ethanol was added successively. The extracts were then concentrated under reduced pressure and controlled temperature for dryness and were stored for stabilization at a specific temperature. Glycerin was applied to the binder and polymer content, the water mixture in a beaker. This forms liquid dispersion and displays the property of slight swelling. The Punica leaf extract, neem oil, and Jamun powder were added to the liquid dispersion. Using a water bath, melted oils together with the base in a separate beaker. Skin whitener and preservative were gradually incorporated along with all other components. Triturated all ingredients above and the requisite consistency was established, which forms poly-herbal anti-aging cream.

\section{Results and discussion}

\section{Evaluation of cream}

There are various evaluation parameters for cream. For this work, the evaluation parameters chosen are Organoleptic evaluation, Microbial Count test, Stability Studies, pH determination, homogeneity determination, wetness determination, smear determination, emolliency determination, viscosity determination, dilution test, dye solubility test.

\section{Organoleptic evaluation}

The cream formulated was evaluated for its organoleptic properties (color, state, and odor). The appearance of the cream was analyzed by its color and roughness visually and by touch. Results are listed in Table No. 2.

\begin{tabular}{|c|c|c|}
\hline Sr. No. & Specification & Limit \\
\hline $\mathbf{1}$ & State & Semi-solid \\
\hline $\mathbf{2}$ & Color & Greyish white \\
\hline $\mathbf{3}$ & Odor & Characteristic \\
\hline $\mathbf{4}$ & Texture & Smooth \\
\hline
\end{tabular}

Table 2. Organoleptic Properties.

\section{Test for microbial growth in formulated creams}

This method was applied from the work of Matangi and Team in the year $2014^{3}$. Here, Streak Plate Method ${ }^{64}$ was used, where the formulated creams were inoculated in a plate with the Muller Hinton agar media. Along with that, a control group was made without the cream for comparison. The plates were kept in the incubator and are incubated for 24 hours at $37^{\circ} \mathrm{C}$. After the incubation period, plates were taken out and analyzed for microbial growth by comparing them with the control. Results are listed in Table 3.

\section{Stability studies}

Thermal stability testing of cream was done at room temperature with relative humidity $(\mathrm{RH}) 65 \%$; results are listed in Table 4. To assess the drug and formulation stability for an extended period, accelerated stability studies were done according to ICH guidelines; the results are listed in Table 5. 


\begin{tabular}{|c|c|c|c|}
\hline Sr. No. & Microbial Load & Limits & Result \\
\hline $\mathbf{1}$ & Total Microbial Count & Not More than 100 & 82 \\
\hline $\mathbf{2}$ & Limit Tests: E. coli & No Characteristic Colonies & Complies \\
\hline
\end{tabular}

Table 3. Microbial Test.

\begin{tabular}{|c|c|c|c|c|c|}
\hline $\begin{array}{l}\text { Sr. } \\
\text { No }\end{array}$ & Thermal & F1 & F2 & F3 & F4 \\
\hline 1 & $\begin{array}{l}\text { Stability (at } \\
\text { RH } 65 \% \\
\text { and } 30^{+}{ }^{\circ} \mathrm{C} \text { ) }\end{array}$ & $\begin{array}{c}\text { Stable, no oil } \\
\text { separation }\end{array}$ & $\begin{array}{c}\text { Stable, no oil } \\
\text { separation }\end{array}$ & $\begin{array}{c}\text { Stable, no oil } \\
\text { separation }\end{array}$ & $\begin{array}{l}\text { Stable, no oil } \\
\text { separation }\end{array}$ \\
\hline
\end{tabular}

Table 4. Thermal stability determination.

\begin{tabular}{|c|c|c|c|c|c|c|c|c|}
\hline \multirow{2}{*}{$\begin{array}{l}\text { Stability } \\
\text { Studies }\end{array}$} & \multicolumn{2}{|c|}{ F1 } & \multicolumn{2}{|c|}{ F2 } & \multicolumn{2}{|c|}{ F3 } & \multicolumn{2}{|c|}{ F4 } \\
\hline & Initial & $\begin{array}{l}\text { After } \\
7 \text { days }\end{array}$ & Initial & $\begin{array}{c}\text { After } 7 \\
\text { days }\end{array}$ & Initial & $\begin{array}{l}\text { After } \\
7 \text { days }\end{array}$ & Initial & $\begin{array}{c}\text { After } 7 \\
\text { days }\end{array}$ \\
\hline $\begin{array}{c}\text { Physical } \\
\text { Appearance }\end{array}$ & $\begin{array}{l}\text { Semi- } \\
\text { solid }\end{array}$ & $\begin{array}{l}\text { Semi- } \\
\text { solid }\end{array}$ & $\begin{array}{l}\text { Semi- } \\
\text { solid }\end{array}$ & $\begin{array}{l}\text { Semi- } \\
\text { solid }\end{array}$ & $\begin{array}{l}\text { Semi- } \\
\text { solid }\end{array}$ & $\begin{array}{l}\text { Semi- } \\
\text { solid }\end{array}$ & $\begin{array}{l}\text { Semi- } \\
\text { solid }\end{array}$ & $\begin{array}{l}\text { Semi- } \\
\text { solid }\end{array}$ \\
\hline Texture & Ok & Ok & Ok & Ok & Ok & $\mathrm{Ok}$ & Ok & Ok \\
\hline Color & White & White & White & White & White & White & White & White \\
\hline $\begin{array}{l}\text { Thermal } \\
\text { Stability }\end{array}$ & Ok & Ok & Ok & Ok & Ok & Ok & Ok & $\mathrm{Ok}$ \\
\hline $\begin{array}{l}\text { Degradation } \\
\text { Of The Product }\end{array}$ & Nil & Nil & Nil & Nil & Nil & Nil & Nil & Nil \\
\hline
\end{tabular}

Table 5. Accelerated Stability Studies.

\section{Determination of Homogeneity}

The formulations were tested for homogeneity by touch for texture and by visual appearance. Result obtained of each formulation is given in Table No. 6,7,8,9.

\section{Determination of the type of smear}

It was determined by applying the cream on the surface of the skin of a human volunteer (Self, no ethical permission need as it is non-toxic, natural, and safe components which makes it exceptional ${ }^{65}$. After applying the cream, the type of smear or film formed on the skin was checked. Result obtained of each formulation is given in Table No. 6,7,8,9.

\section{Determination of Viscosity}

The viscosity determinations were carried out using a Brookfield viscometer (DV II + Pro model) using spindle number S-64 at $20 \mathrm{rpm}$ at a temperature of $25^{\circ} \mathrm{C}$. Result obtained of each formulation is given in Table No. 6,7,8,9.

\section{Determination of $\mathrm{pH}$}

Accurately weighed $1 \mathrm{gm}$ of the sample was dispersed in $100 \mathrm{ml}$ of water. The $\mathrm{pH}$ of the suspension was set at $27^{\circ} \mathrm{C}$ using a digital $\mathrm{pH}$ meter. Result obtained of each formulation is given in Table No. 6,7,8,9.

\section{Spread ability Test}

This method was applied from the work of Dhase and Team in the year 2014, Chen and Team in the year 2016 $66,67$.
Spread ability can be expressed by the extent of the area to which the topical application spreads when applied to the affected parts on the skin and the curative value of the formulation also hang-on upon its spreading value. Hence, it was found obligatory to determine the spread ability of the formulation. For this purpose, a small amount of about $23 \mathrm{~cm}$ of each formulation was applied in between two glass slides, and they were pressed together to obtain a film of uniform thickness by placing $1000 \mathrm{gm}$ weight for 5 minutes. Thereafter a weight of $10 \mathrm{gm}$ was added to the pan, and the top plate was subjected to pull with the help of string attached to the hook. The time in which the upper glass slide moves over the lower plate to cover a distance of $10 \mathrm{~cm}$ was noted. The Spread ability (S) can be determined using the formula ${ }^{66,67}$.

$\mathrm{S}=(\mathrm{m} \times \mathrm{L}) / \mathrm{T}$,

Where S-Spread ability;

$m$ - Weight binds to the upper glass slide,

$L$ - Length budged on a glass slide

$T$ - Time is taken.

Results obtained are given in Table No. 10. The cream was found to be easily spreadable.

\section{Dye solubility test}

This method was applied from the work of Dhase and Team in the year $2014^{66}$. In this test, a small sample is mixed with a water-soluble dye and observed under the microscope. If the continuous phase appears red, the cream is O/W (Oil in Water) type as the water is in the external phase, and the dye will dissolve in it to give color. If the scattered globules appear red and continuous phase colorless, they are W/O (Water in 
Oil) type. Likewise, if an oil-soluble dye such as Scarlet red or Sudan III is put on to an emulsion and the continuous phase appears red, it is w/o emulsion. Following the procedure, red color was observed; hence, it was 0/W type of cream ${ }^{66}$.

\section{Dilution test}

This method was applied from the work of Dhase and Team in the year 201466. In this test, the cream is diluted either with oil or water. If the cream is o/w type and diluted with water, it will remain stable as water is the dispersion medium, but if it is diluted with oil, the cream will break as oil and water are not miscible. Oil in water emulsion can be diluted with an aqueous solvent, whereas water in oil emulsion can be diluted with an oily liquid. Following the procedure, it was found to be O/W type of cream as because the obtained product was stable ${ }^{66}$.

\begin{tabular}{|c|c|c|c|c|c|}
\hline $\begin{array}{c}\text { Time Interval } \\
\text { (Day) }\end{array}$ & Homogeneity & Type of smear & Viscosity(cp) & Physical changes & $\mathbf{p H}$ \\
\hline $\mathbf{0}$ & Excellent & Excellent & 12.005 & $\begin{array}{c}\text { No change in } \\
\text { color and odor }\end{array}$ & 6.1 \\
\hline $\mathbf{5}$ & Good & Excellent & 12.005 & $\begin{array}{c}\text { No change in } \\
\text { color and odor }\end{array}$ & 6.1 \\
\hline $\mathbf{1 5}$ & Good & Good & 12.004 & $\begin{array}{c}\text { No change in } \\
\text { color and odor }\end{array}$ & 6.1 \\
\hline $\mathbf{2 0}$ & Good & Good & 12.004 & $\begin{array}{l}\text { No change in } \\
\text { color and odor }\end{array}$ & 6.1 \\
\hline $\mathbf{3 0}$ & Good & Good & 12.003 & $\begin{array}{c}\text { No change in } \\
\text { color and odor }\end{array}$ & 6.1 \\
\hline
\end{tabular}

Table 6. Formulation 1

\begin{tabular}{|c|c|c|c|c|c|}
\hline $\begin{array}{c}\text { Time Interval } \\
\text { (Day) }\end{array}$ & Homogeneity & $\begin{array}{c}\text { Type of } \\
\text { smear }\end{array}$ & Viscosity(cp) & Physical changes & pH \\
\hline $\mathbf{0}$ & Excellent & Excellent & 12.521 & $\begin{array}{c}\text { No change in color } \\
\text { and odor }\end{array}$ & 5.7 \\
\hline $\mathbf{5}$ & Excellent & Excellent & 12.500 & $\begin{array}{c}\text { No change in color } \\
\text { and odor }\end{array}$ & 5.7 \\
\hline $\mathbf{1 5}$ & Good & Good & 12.510 & $\begin{array}{c}\text { No change in color } \\
\text { and odor }\end{array}$ & 5.7 \\
\hline $\mathbf{2 0}$ & Average & Good & 12.512 & $\begin{array}{c}\text { No change in color } \\
\text { and odor }\end{array}$ & 5.7 \\
\hline $\mathbf{3 0}$ & Average & Good & 12.515 & $\begin{array}{c}\text { No change in color } \\
\text { and odor }\end{array}$ & 5.7 \\
\hline
\end{tabular}

Table 7. Formulation 2.

\begin{tabular}{|c|c|c|c|c|c|}
\hline $\begin{array}{c}\text { Time Interval } \\
\text { (Day) }\end{array}$ & Homogeneity & $\begin{array}{c}\text { Type of } \\
\text { smear }\end{array}$ & Viscosity(cp) & Physical changes & pH \\
\hline $\mathbf{0}$ & Excellent & Excellent & 12.499 & $\begin{array}{c}\text { No change in } \\
\text { color and odor }\end{array}$ & 5.6 \\
\hline $\mathbf{5}$ & Excellent & Excellent & 12.450 & $\begin{array}{c}\text { No change in } \\
\text { color and odor }\end{array}$ & 5.6 \\
\hline $\mathbf{1 5}$ & Good & Good & 12.465 & $\begin{array}{c}\text { No change in } \\
\text { color and odor }\end{array}$ & 5.6 \\
\hline $\mathbf{2 0}$ & Good & Good & 12.460 & $\begin{array}{c}\text { No change in } \\
\text { color and odor } \\
\text { No change in } \\
\text { color and odor }\end{array}$ & 5.6 \\
\hline $\mathbf{3 0}$ & Average & Good & 12.455 & \begin{tabular}{c}
5.6 \\
\hline
\end{tabular}
\end{tabular}

Table 8. Formulation 3
The cream was the o/w type of emulsion. Due to the base material, the proper addition of surfactants to its proper quantity, and the proper combination of all the excipients, it was stable. The proper ratio of all ingredients of excipients with the active ingredients also reasons for the stability. During the formulation, the oil phase and water phase are mixed, and it was also responsible for the stability of that cream.

After the formulation of cream by checking all these different evaluation parameters, the 4 formulated creams showed good homogeneity when the creams were observed by touch and visual test. The color and physical appearance (color \& odor) were not changed during storage; it may happen due to preservatives' helpful addition.

All the individual $\mathrm{pH}$ noted for the formulated herbal creams were F1 - 6.1, F2 - 5.7, F3 - 5.6, F4 - 5.9. The formu- 


\begin{tabular}{|c|c|c|c|c|c|}
\hline $\begin{array}{c}\text { Time Interval } \\
\text { (Day) }\end{array}$ & Homogeneity & Type of smear & Viscosity(cp) & $\begin{array}{c}\text { Physical } \\
\text { changes }\end{array}$ & $\mathbf{p H}$ \\
\hline $\mathbf{0}$ & Excellent & Excellent & 12.008 & $\begin{array}{c}\text { No change in } \\
\text { color and odor }\end{array}$ & 5.9 \\
\hline $\mathbf{5}$ & Excellent & Excellent & 12.005 & $\begin{array}{c}\text { No change in } \\
\text { color and odor }\end{array}$ & 5.9 \\
\hline $\mathbf{1 5}$ & Good & Good & 12.002 & $\begin{array}{c}\text { No change in } \\
\text { color and odor }\end{array}$ & 5.9 \\
\hline $\mathbf{2 0}$ & Average & Good & 12.006 & $\begin{array}{c}\text { No change in } \\
\text { color and odor }\end{array}$ & 5.9 \\
\hline $\mathbf{3 0}$ & Average & Good & 12.008 & $\begin{array}{c}\text { No change in } \\
\text { color and odour }\end{array}$ & 5.9 \\
\hline
\end{tabular}

Table 9. Formulation 4.

\begin{tabular}{|c|c|c|c|c|c|}
\hline \multirow{2}{*}{$\begin{array}{c}\text { Sr. } \\
\text { No. }\end{array}$} & Time (Sec) & \multicolumn{4}{|c|}{ Spread ability Studies (cm) } \\
\cline { 3 - 6 } & & F1 & F2 & F3 & F4 \\
\hline $\mathbf{1}$ & $\mathbf{1 5}$ & 13.5 & 13.6 & 14.3 & 14.4 \\
\hline $\mathbf{2}$ & $\mathbf{2 0}$ & 14.1 & 13.1 & 14.1 & 13.6 \\
\hline $\mathbf{3}$ & $\mathbf{2 5}$ & 13.3 & 14.6 & 13.6 & 13.7 \\
\hline
\end{tabular}

skin $\mathrm{pH}$. As per the result, it was found that Trial F3 has better consistency of formulation of cream in the combination of different excipients in their quantities.

The prepared formulations showed no affirmation of phase separation, had good spread ability and had good consistency during the study period. Stability parameters like visual appearance, texture, viscosity, and fragrance of the formulations reflected no significant variation during the study period. The prepared formulations showed an acceptable $\mathrm{pH}$ range that was approximately $\mathrm{pH}$ 5.6; it confirms the compatibility of the formulations with skin secretions.

\section{Conclusions}

In this project work, the selected active ingredients are Punica leaf extract, carrot powder, Jamun powder, and neem oil. These all ingredients are cheap and readily available in the market, including all these ingredients, the selected excipients-beeswax, grape seed oil, almond oil, stearic acid, lanolin as base material; Sodium benzoate as a preservative; Cetyl alcohol as emollient and surfactants; peppermint oil as a flavoring agent for all type of formulation like F1, F2, F3 \& F4. F3 stood out to be the better formulation concerning results obtained.

From the existing examination and acquired results, it could be concluded that it's possible to broaden poly natural cream containing natural extracts with anti-oxidants belongings, which may be formulated to act as a barrier or to defend skin and make cosmetic cream.

\section{Acknowledgment}

The authors would like to thank Mr. Mayukh Jana (Associate Professor, Department of Pharmaceutics, Bharat Technology, Uluberia) to help during this investigation.

\section{Source of Funding}

Nil

\section{Conflict Of Interest}

Nil
Table 10. Spread ability Test.

\section{Bibliographic references}

1. Watson REB, Ogden S, Cotterell LF, et al. A cosmetic 'anti-ageing' product improves photoaged skin: a double-blind, randomized controlled trial. $\mathrm{Br} J$ Dermatol. 2009;161(2):419-426. doi:10.1111/j.1365-2133.2009.09216.x

2. Kaur IP, Kapila M, Agrawal R. Role of novel delivery systems in developing topical anti-oxidants as therapeutics to combat photoageing. Ageing Res Rev. 2007;6(4):271-288. doi:10.1016/j. arr.2007.08.006

3. Matangi SP, Mamidi SA, Gulshan MD, Raghavamma STV, Nadendla RR. Formulation and Evaluation of Anti Aging Poly Herbal Cream. Int J Pharm Sci Rev Res. 2014;24(22):133-136.

4. Saraf S, Kaur C. Phytoconstituents as photoprotective novel cosmetic formulations. Pharmacogn Rev. 2010;4(7):1. doi:10.4103/0973-7847.65319

5. Draelos ZD, Thaman LA, eds. Cosmetic Formulation of Skin Care Products. In: Cosmetic Formulation of Skin Care Products. 0 ed. CRC Press; 2005:25-26. doi:10.3109/9781420020854-5

6. Chattopadhyay PK. Herbal Cosmetics \& Ayurvedic Medicines (EOU). In: Herbal Cosmetics \& Ayurvedic Medicines (EOU). 3rd Revised Edition. Niir Project Consultancy Services; 2013. https:// books.google.co.in/books? id=cuCoDAAAQBAJ\&printsec=frontcover\&source=gbs_ge_summary_r\&cad=0\#v=0nepage \&q\&f=false

7. Russell R. Cosmetics Use. In: Encyclopedia of Body Image and Human Appearance. Elsevier; 2012:366-371. doi:10.1016/B9780-12-384925-0.00058-4

8. Datta HS, Paramesh R. Trends in aging and skin care: Ayurvedic concepts. J Ayurveda Integr Med. 2010;1(2):110-113. doi:10.4103/0975-9476.65081

9. Kumar D, Rajora G, Parkash O, Himanshu, Antil M, Kumar V. Herbal cosmetics: An overview. Int J Adv Sci Res. 2016;1(4):36-41.

10. Mishra A, Mishra A, Chattopadhyay P. Herbal Cosmeceuticals for Photoprotection from Ultraviolet B Radiation: A Review. Trop J Pharm Res. 2011;10(3). doi:10.4314/tjpr.v10i3.7

11. Geesin JC, Darr D, Kaufman R, Murad S, Pinnell SR. Ascorbic acid specifically increases type I and type III procollagen messenger RNA levels in human skin fibroblast. J Invest Dermatol. 1988;90(4):420-424. doi:10.1111/1523-1747.ep12460849

12. Dureja H, Kaushik D, Gupta M, Kumar V, Lather V. Cosmeceuticals: An emerging concept. Indian J Pharmacol. 2005;37(3):155. doi:10.4103/0253-7613.16211 
13. Rajvanshi A, Sharma S, Khokra SL, Sahu RK, Jangde R. Formulation and evaluation of Cyperus rotundus and Cucumis sativus based herbal face cream. Pharmacologyonline. 2011;2:1238-1244.

14. Saraf S, Ashawat MS., Baghel M. Herbal Cosmetics: "Trends in Skin Care Formulation." Pharmacogn Rev. 2009;3(5):82-89.

15. Viswanatha G, Venkataranganna M, Prasad N, Ashok G. Evaluation of anti-epileptic activity of leaf extracts of Punica granatum on experimental models of epilepsy in mice. J Intercult Ethnopharmacol. 2016;5(4):415. doi:10.5455/jice.20160904102857

16. Basiri S. Evaluation of anti-oxidant and antiradical properties of Pomegranate (Punica granatum L.) seed and defatted seed extracts. J Food Sci Technol. 2015;52(2):1117-1123. doi:10.1007/ s13197-013-1102-z

17. Wang D, Özen C, Abu-Reidah IM, et al. Vasculoprotective Effects of Pomegranate (Punica granatum L.). Front Pharmacol. 2018;9:544. doi:10.3389/fphar.2018.00544

18. Jurenka JS. Therapeutic applications of pomegranate (Punica granatum L.): a review. Altern Med Rev J Clin Ther. 2008;13(2):128-144.

19. Lee C-J, Chen L-G, Liang W-L, Wang C-C. Multiple Activities of Punica granatum Linne against Acne Vulgaris. Int J Mol Sci. 2017;18(1):141. doi:10.3390/ijms18010141

20. Fellah B, Bannour M, Rocchetti G, Lucini L, Ferchichi A. Phenolic profiling and anti-oxidant capacity in flowers, leaves and peels of Tunisian cultivars of Punica granatum L. J Food Sci Technol. 2018;55(9):3606-3615. doi:10.1007/s13197-018-3286-8

21. Lei F, Zhang XN, Wang W, et al. Evidence of anti-obesity effects of the pomegranate leaf extract in high-fat diet induced obese mice. Int J Obes. 2007;31(6):1023-1029. doi:10.1038/sj.ijo.0803502

22. Mohajer S, Taha RM, Azmi SZ. Phytochemical screening and potential of natural dye colourant from pomegranate (Punica granatum L.). Pigment Resin Technol. 2016;45(1):38-44. doi:10.1108/ PRT-10-2014-0100

23. Kato K, Vo PHT, Furuyashiki T, Kamasaka H, Kuriki T. Co-ingestion of whole almonds and almond oil with carbohydrate suppresses postprandial glycaemia in mice in an insulin-dependent and insulin-independent manner. J Nutr Sci. 2019;8:e25. doi:10.1017/ jns.2019.22

24. Mericli F, Becer E, Kabadayı $\mathrm{H}$, et al. Fatty acid composition and anti-cancer activity in colon carcinoma cell lines of Prunus dulcis seed oil. Pharm Biol. 2017;55(1):1239-1248. doi:10.1080/138802 09.2017.1296003

25. Musarra-Pizzo M, Ginestra G, Smeriglio A, Pennisi R, Sciortino MT, Mandalari G. The Anti-microbial and Antiviral Activity of Polyphenols from Almond (Prunus dulcis L.) Skin. Nutrients. 2019;11(10):2355. doi:10.3390/nu11102355

26. Franklin LM, Mitchell AE. Review of the Sensory and Chemical Characteristics of Almond (Prunus dulcis) Flavor. J Agric Food Chem. 2019;67(10):2743-2753. doi:10.1021/acs.jafc.8b06606

27. Ahmad Z. The uses and properties of almond oil. Complement Ther Clin Pract. 2010;16(1):10-12. doi:10.1016/j.ctcp.2009.06.015

28. Barreca D, Nabavi SM, Sureda A, et al. Almonds (Prunus Dulcis Mill. D. A. Webb): A Source of Nutrients and Health-Promoting Compounds. Nutrients. 2020;12(3):672. doi:10.3390/nu12030672

29. Buckle J. Clinical aromatherapy. Therapeutic uses for essential oils. Adv Nurse Pract. 2002;10(5):67-68, 88.

30.Lardos A. The botanical materia medica of the latrosophikon-A collection of prescriptions from a monastery in Cyprus. J Ethnopharmacol. 2006;104(3):387-406. doi:10.1016/j.jep.2005.12.035

31. Simon D, Nobbe S, Nägeli M, et al. Short- and long-term effects of two emollients on itching and skin restoration in xerotic eczema. Dermatol Ther. 2018;31(6):e12692. doi:10.1111/dth.12692

32. Gajera HP, Gevariya SN, Hirpara DG, Patel SV, Golakiya BA. Anti-diabetic and anti-oxidant functionality associated with phenolic constituents from fruit parts of indigenous black jamun (Syzygium cumini L.) landraces. J Food Sci Technol. 2017;54(10):31803191. doi:10.1007/s13197-017-2756-8

33. Aqil F, Gupta A, Munagala R, et al. Antioxidant and Antiproliferative Activities of Anthocyanin/Ellagitannin-Enriched Extracts From Syzygium cumini L. (Jamun, the Indian Blackberry). Nutr Cancer. 2012;64(3):428-438. doi:10.1080/01635581.2012.657766
34. Jagetia GC, Baliga MS, Venkatesh P. Influence of Seed Extract of Syzygium Cumini (Jamun) on Mice Exposed to Different Doses of y-radiation. J Radiat Res (Tokyo). 2005;46(1):59-65. doi:10.1269/ jrr.46.59

35. Ayyanar M, Subash-Babu P. Syzygium cumini (L.) Skeels: a review of its phytochemical constituents and traditional uses. Asian Pac J Trop Biomed. 2012;2(3):240-246. doi:10.1016/S22211691(12)60050-1

36. Benherlal PS, Arumughan C. Chemical composition and in vitro anti-oxidant studies on Syzygium cumini fruit: Composition and anti-oxidant studies on S. cumini fruit. J Sci Food Agric. 2007;87(14):2560-2569. doi:10.1002/jsfa.2957

37. Gajera HP, Gevariya SN, Patel SV, Golakiya BA. Nutritional profile and molecular fingerprints of indigenous black jamun (Syzygium cumini L.) landraces. J Food Sci Technol. 2018;55(2):730-739. doi:10.1007/s13197-017-2984-y

38.Sehwag S, Upadhyay R, Das M. Optimization and multivariate accelerated shelf life testing (MASLT) of a low glycemic whole jamun (Syzygium cumini L.) confection with tailored quality and functional attributes. J Food Sci Technol. 2018;55(12):48874900. doi:10.1007/s13197-018-3423-4

39. Ahmed R, Tariq M, Hussain M, et al. Phenolic contents-based assessment of therapeutic potential of Syzygium cumini leaves extract. Bakhsh A, ed. PLOS ONE. 2019;14(8):e0221318. doi:10.1371/journal.pone.0221318

40.Pérez Gutiérrez RM, Hernández Luna H, Hernández Garrido S. Antioxidant Activity Of Tagetes Erecta Essential Oil. J Chil Chem Soc. 2006;51(2):883-886. doi:10.4067/S0717-97072006000200010

41. Singh YP, Dwivedi R, Dwivedi SV. Effect of biofertilizers and graded dose of nitrogen on growth and flower yield of calendula (Callendula officinalis) ; 8 (2): 957-958. Plant Arch. 2008;8(2):957958.

42. Karabacak CE, Karabacak H. Factors Affecting Carotenoid Amount In Carrots (Daucus Carota). E-J New World Sci Acad. 2019;14(2):29-39. doi:10.12739/NWSA.2019.14.2.5A0113

43. Dosti MP, Mills JP, Simon PW, Tanumihardjo SA. Bioavailability of $\beta$-carotene $(B C)$ from purple carrots is the same as typical orange carrots while high- $\beta C$ carrots increase $\beta C$ stores in Mongolian gerbils (Meriones unguiculatus). Br J Nutr. 2006;96(2):258-267. doi:10.1079/BJN20061562

44.Bothra Nursery. Neem Tree. Bothra Nursery. Published 2015. Accessed 2 December, 2020. http://www.bothranursery.com/product/forest-and-roadside-plants/neem-tree/

45. Alravat Products. The Magnificent Neem Tree. Top-Tree-House Designs Tree House Designs. Published 10 May, 2016. Accessed 2 December, 2020. https://toptreehouse.wordpress. com/2016/05/10/30/

46. Alzohairy MA. Therapeutics Role of Azadirachta indica (Neem) and Their Active Constituents in Diseases Prevention and Treatment. Evid Based Complement Alternat Med. 2016;2016:1-11. doi:10.1155/2016/7382506

47. Paul R, Prasad M, Sah NK. Anti-cancer biology of Azadirachta indica $L$ (neem): A mini review. Cancer Biol Ther. 2011;12(6):467476. doi:10.4161/cbt.12.6.16850

48.Zanuncio JC, Mourão SA, Martínez LC, et al. Toxic effects of the neem oil (Azadirachta indica) formulation on the stink bug predator, Podisus nigrispinus (Heteroptera: Pentatomidae). Sci Rep. 2016;6(1):30261. doi:10.1038/srep30261

49.Lakshmi T, Krishnan V, Rajendran R, Madhusudhanan N. Azadirachta indica : A herbal panacea in dentistry - An update. Pharmacogn Rev. 2015;9(17):41. doi:10.4103/0973-7847.156337

50.Patel SM, Nagulapalli Venkata KC, Bhattacharyya P, Sethi G, Bishayee A. Potential of neem ( Azadirachta indica L.) for prevention and treatment of oncologic diseases. Semin Cancer Biol. 2016;40-41:100-115. doi:10.1016/j.semcancer.2016.03.002

51. Ashokhan S, Othman R, Abd Rahim MH, Karsani SA, Yaacob JS. Effect of Plant Growth Regulators on Coloured Callus Formation and Accumulation of Azadirachtin, an Essential Biopesticide in Azadirachta indica. Plants. 2020;9(3):352. doi:10.3390/ plants9030352 
52. Gomes SA, Paula AR, Ribeiro A, et al. Neem oil increases the ef ficiency of the entomopathogenic fungus Metarhizium anisopliae for the control of Aedes aegypti (Diptera: Culicidae) larvae. Parasit Vectors. 2015;8(1):669. doi:10.1186/s13071-015-1280-9

53. Moga M, Bălan A, Anastasiu C, Dimienescu O, Neculoiu C, Gavriș C. An Overview on the Anticancer Activity of Azadirachta indica (Neem) in Gynecological Cancers. Int J Mol Sci. 2018;19(12):3898 doi:10.3390/ijms19123898

54. Jeba Malar TRJ, Antonyswamy J, Vijayaraghavan P, et al. In-vitro phytochemical and pharmacological bio-efficacy studies on Azadirachta indica A. Juss and Melia azedarach Linn for anti-cancer activity. Saudi J Biol Sci. 2020;27(2):682-688. doi:10.1016/j. sjbs.2019.11.024

55. Yilmaz Y, Toledo RT. Oxygen radical absorbance capacities of grape/wine industry by-products and effect of solvent type on extraction of grape seed polyphenols. J Food Compos Anal. 2006;19(1):41-48. doi:10.1016/j.jfca.2004.10.009

56. Shi J, Yu J, Pohorly JE, Kakuda Y. Polyphenolics in Grape SeedsBiochemistry and Functionality. J Med Food. 2003;6(4):291-299. doi:10.1089/109662003772519831

57. Shivananda Nayak B, Dan Ramdath D, Marshall JR, Isitor G, Xue S, Shi J. Wound-healing Properties of the Oils of Vitis vinifera and Vaccinium macrocarpon: Wound Healing Activity Of Grape And Cranberry Oils. Phytother Res. 2011;25(8):1201-1208. doi:10.1002/ptr.3363

58. Micheli L, Mattoli L, Maidecchi A, Pacini A, Ghelardini C, Di Cesare Mannelli L. Effect of Vitis vinifera hydroalcoholic extract against oxaliplatin neurotoxicity: in vitro and in vivo evidence. Sci Rep. 2018:8(1):14364. doi:10.1038/s41598-018-32691-w

59.Chao CY, Mani MP, Jaganathan SK. Engineering electrospun multicomponent polyurethane scaffolding platform comprising grapeseed oil and honey/propolis for bone tissue regeneration. Mishra YK, ed. PLOS ONE. 2018;13(10):e0205699. doi:10.1371/ journal.pone.0205699
60.Leparmarai PT, Sinz S, Kunz C, et al. Transfer of total phenols from a grapeseed-supplemented diet to dairy sheep and goat milk, and effects on performance and milk quality. J Anim Sci. 2019;97(4):1840-1851. doi:10.1093/jas/skz046

61. Oh JY, Park MA, Kim YC. Peppermint Oil Promotes Hair Growth without Toxic Signs. Toxicol Res. 2014;30(4):297-304. doi:10.5487/TR.2014.30.4.297

62. McKay DL, Blumberg JB. A review of the bioactivity and potential health benefits of peppermint tea (Mentha piperita L.). Phytother Res. 2006;20(8):619-633. doi:10.1002/ptr.1936

63. Chumpitazi BP, Kearns GL, Shulman RJ. Review article: the physiological effects and safety of peppermint oil and its efficacy in irritable bowel syndrome and other functional disorders. Aliment Pharmacol Ther. 2018:47(6):738-752. doi:10.1111/apt.14519

64.Sanders ER. Aseptic Laboratory Techniques: Plating Methods. J Vis Exp. 2012;(63):3064. doi:10.3791/3064

65. Hanley BP, Bains W, Church G. Review of Scientific Self-Experimentation: Ethics History, Regulation, Scenarios, and Views Among Ethics Committees and Prominent Scientists. Rejuvenation Res. 2019;22(1):31-42. doi:10.1089/rej.2018.2059

66. Dhase AS, Khadbadi SS, Saboo SS. Formulation and Evaluation of Vanishing Herbal Cream of Crude Drugs. Am J Ethnomedicine. 2014:1(5):313-318

67. Chen MX, Alexander KS, Baki G. Formulation and Evaluation of Antibacterial Creams and Gels Containing Metal lons for Topical Application. J Pharm. 2016;2016:1-10. doi:10.1155/2016/5754349

Received: 1 May 2021

Accepted: 4 July 2021 